\title{
The dynamics and existence of Islamic party in 2019 general election: case study of Prosperous Justice Party (PKS)
}

Muh. Haris

Diponegoro University

E-mail:muh.hariss10@gmail.com

Yuwanto

Diponegoro University

E-mail:yuwantosaja@yahoo.com

Teguh Yuwono

Diponegoro University

E-mail: teguhyuwonos@gmail.com

Nur Hidayat Sardini

Diponegoro University

E-mail: nhsardini@gmail.com

DOI: 10.18326/ijims.v10i2.409-432 


\begin{abstract}
The development of Islam in the political arena in Indonesia is interesting to be analyzed comprehensively. The purpose of this paper is to analyze the existence of Islamic political parties after the 2019 simultaneous general elections. The main problem in political life in Indonesia is the decline of public trust in political parties. One of the main reasons is the corruption case that ensnared politicians. The presence of Islamic political parties is hopefully able to bring a change and alter the ugly stigma from the society towards the political parties. This study is qualitative in nature with a case study of PKS as a participant in the 2019 simultaneous general election, using an institutional assessment of the existence of political parties. The dynamics and existence of PKS before the 2019 general election were categorically high. It means that the PKS movement was active in society by offering strategic programs and policies for voters. PKS has a structured party system starting from the regeneration system to constituent treatment that can increase the number of voters in the 2019 elections. This research shows that regeneration carried out through tarbiyah can instill party ideology in cadres, but fails to raise the party in a fast time. Based on the political dynamics of PKS during the Jokowi-JK administration period 2014-2019, identity politics was able to increase voter participation and increase PKS votes in the 2019 elections.
\end{abstract}

Perkembangan Islam dalam kancah politik di Indonesia menarik untuk dianalisis secara mendalam. Tulisan ini bertujuan untuk menganalisis eksistensi partai politik Islam pasca pemilihan umum serentak tahun 2019. Permasalahan utama dalam kehidupan politik di Indonesia adalah menurunnya kepercayaan masyarakat kepada partai politik. Salah satu alasan utamanya adalah kasus korupsi yang menjerat para anggota politikus. Hadirnya partai politik Islam diharapkan mampu membawa perubahan dan mengubah stigma buruk masyarakat terhadap partai politik. Metode yang digunakan dalam tulisan ini adalah metode kualtatif dengan studi kasus PKS sebagai peserta pemilihan umum serentak tahun 2019, dengan menggunakan tinjauan pengukuran eksistensi partai politik berdasarkan kelembagaan. Dinamika dan eksistensi PKS menjelang pemilihan umum 2019 dikategorikan tinggi. Artinya pergerakan PKS yang aktif di tengah masyarakat dengan menawarkan program dan kebijakan strategis bagi pemilih. PKS memiliki sistem kepartaian yang terstruktur dimulai dari sistem kaderisasi hingga perawatan konstituen yang mampu meningkatkan jumlah pemilih pada 
pemilu 2019. Penelitian ini menyimpulkan bahwa kaderisasi yang dilakukan melalui tarbiyah mampu menanamkan ideologi partai kepada kader, namun gagal dalam membesarkan partai dalam waktu cepat. Berdasarkan dinamika politik PKS pada periode pemerintahan Jokowi-JK tahun 2014-2019, bahwa politik identitas mampu meningkatkan partisipasi pemilih dan meningkatkan perolehan suara PKS pada Pemilu 2019.

Keywords: PKS; Existence; General Election; Political Parties; Tarbiyah

\section{Introduction}

The existence of political parties in a country that adopts a democratic system is very important in representing the community groups. The presence of political parties in the community can deliver people's political aspirations and participation. The provision of Article 1 of Law Number 2 of 2011 concerning Political Parties affirms that political parties are national organizations and are formed by a group of Indonesian citizens voluntarily based on the common will and aspirations to fight and defend the political interests of the members, communities, nations, and state, as well as maintaining the integrity of the Negara Kesatuan Republik Indonesia (NKRI; English: Unitary State of the Republic of Indonesia) based on the Pancasila and the 1945 Constitution. The presence of political parties in Indonesia bloomed after the collapse of the Orde Baru (English: New Order) because the government ensures the freedom of the people in expressing their opinions in public.

The emergence of new political parties after the New Order phenomenon was comparable with the emergence of Islamic political parties. The emergence of the power of Islamic political parties in the 1999 Pemilu (Indonesian: Pemilihan Umum; English: general election) signaled a change or shift in the map of political power in Indonesia. The Islamic circle's influence on the reign was evidence of the dominance of Islamic 
political power. ${ }^{1}$ Islamic political parties have developed in Indonesia since the beginning of the elections in 1955. The 2019 elections were the culmination of direct elections and were also the first time to be held simultaneously to elect the President and Vice President and to elect legislative members at the national and regional levels.

The development of Islamic political parties has decreased, both in quantity and electability. One of the influencing factors is the inability to present attractive programs for the people and the inability to yield innovative cadres who can become role models. ${ }^{2}$ The phenomenon of the 2014 general election illustrates that Islamic political parties have failed to maintain their electoral vote. The reason is the inability of Islamic political parties to change their ideology in politics, internal grouping, and identity crises. Islamic political parties were not able to solve problems that had previously occurred in the previous administration period which resulted in a decrease in the electoral votes in the 2014 elections. ${ }^{3}$ The 2019 general election was the culmination of democracy in Indonesia, in which the 2019 general election was held simultaneously to elect legislative members at the central and regional levels and to elect the president and vice president. In the 1999 elections consisting of 48 election participants, there were 18 political parties or $37.50 \%$ of them were Islamic-based political parties. The rise of political parties was a manifestation of the emergence of Islamicbased political parties after the New Order. ${ }^{4}$ Hence, it was because, at that time, the New Order regime carried out a de-centralization policy with a

${ }^{1}$ Endang Turmudi, "Islamic Politics in Contemporary Indonesia", Internasional Journal of Political Studies, Volume 2, Number 3 (2016), 1-9.

${ }^{2}$ Ali Thaufan Dwi Saputra, Pergolakan Partai Islam di Tahun Politik, Jakarta: Yayasan Pustaka Obor Indonesia, 2019, 13.

${ }^{3}$ Ahmad Khoirul Umam \& Akhmad Arif Junaidi, "Political Islam: The Shrinking Tren and The Future Trajectory of Islamic Political Parties in Indonesia”, Masyarakat, Kebudayaan dan Politik, Volume 30, Number 1 (2017), 1-12.

${ }^{4}$ Lili Romli, "Partai Islam dan Pemilih Islam di Indonesia", Jurnal Penelitian Politik, Volume 1, No. 1 (2004), 29-48. 
series of policies such as a floating mass, de-politicization of the masses, and de-ideologization by applying Pancasila as the sole principle.

In the 2004 general election, there was a decrease in the general election participants coming from Islamic-based political parties. They consisted of 7 political parties or $29.17 \%$ out of the 24 political parties. Whereas in the 2009 Election there were 11 Islamic-based political parties out of 38 political parties participating in the 2009 general election or $28.95 \%$. The 2014 general election was participated in by 12 political parties, 5 of them were Islamic-based political parties or $41.67 \%$, namely PKB, PKS, PAN, PPP, and PBB. The interesting thing in the 2014 general election was that almost $50 \%$ of the participants are Islamic-based political parties. In 2019, there were 16 political parties participating in the election and among them, there were $31.25 \%$ or 5 Islamic-based political parties namely PKB, PKS, PAN, PPP, and PBB.

$\mathrm{PKS}$ as an Islamic party is an interesting phenomenon to be examined in the arena of politics in Indonesia. PKS as a small and strong Islamic party became a religious-nationalist party, by laying the foundations of Pancasila, opening up the opportunities for the non-Muslim communities to join as PKS cadres in various regions in Indonesia. ${ }^{5}$ The continuity of PKS in the general elections in Indonesia can be seen from the cadres who are promoted by PKS and is elected as the regional heads and deputy regional heads at the regency, city and provincial level. The total number of regional heads, including regents, mayors, and governors from PKS cadres are 29 people from the direct election of the people. From 2005 to 2019, the highest number of PKS cadres who became the regional heads was during 2016. There were 5 cadres who were divided into 2 cadres each to become the regents and mayors, and 1 cadre to become the governor. While the

${ }^{5}$ Dirk Tomsa, "Moderating Islamism in Indonesia: Tracing Patterns of Party Change in the Prosperous Justice Party”, Political Research Quarterly, Volume 65, Number 3 (2012), 486-498. 
cadres who were the deputy regional heads scattered in several regions of Indonesia, 37 of them became the deputy regent, deputy mayor, and deputy governor. During the 2016 period, a total of 8 PKS cadres officially became the deputy regent in the 2015 simultaneous regional election period. The continuity of PKS is seen from the election of regional heads and deputy regional heads both before the election period simultaneously or not simultaneously, PKS has a solid cadre in each election period. Some PKS cadres were able to be elected to the regional head election both as candidates for regional head and deputy regional head candidates. In the simultaneous election period of 2015, 2017, and 2018, PKS cadres won 3 governor's seats namely in West Sumatra Province, West Nusa Tenggara Province, and North Maluku Province.

The modern cadre party must have five characteristics. First, the political elites and professional leaders' groups dominate the role, especially in parliament and have a high responsibility towards the party members under it. Second, to ensure the continuance of the party, the ratio of members/ voters has a low characteristic by having a source of funding and media for recruiting candidates for political office. Third, in attracting voters from a variety of groups, the party does not use the catch-all approach and does not also aim at particular groups and classes. Fourth, a strict vertical structure is kept to maintain the existence of the party and the image of the party which also ensures the ongoing climate of democracy in the internal party. Fifth, the party combines funding sources derived from public subsidies and from members (donations from party members). ${ }^{6}$

The existence of Islamic political parties in Indonesia in passing the democratic party both in the General Election and Pilkada is stagnant,

${ }^{6}$ Ruud A. Koole, "The Vulnerability of the Modern Cadre Party in the Netherlands", in R. S. Katz \& P. Mair (Eds.), How Parties Organize: Change and Adaptation in Party Organizations in Western Democracies, London: SAGE Publications, Inc., 1994. 
without any significant results. Hamayotsu reported that some religious parties were able to survive after adopting moderate ideological views, while other religious parties were unable to survive only relied on party ideology. The two prominent Islamic parties in Indonesia are PKB and PKS. Both parties have experienced which are different from democratic trajectories?.

This study also complements several previous studies, namely completing the assumption of factionalization theory researched by Munandar that factions occur internally in PKS. The complexity of the factionalization or grouping is coupled with several grouping factors, namely attitudes towards strategic resources (money, power, and constituents), educational and professional backgrounds, ethnic backgrounds, and generations who joined the Tarbiyah congregation. The Tarbiyah congregation is a factor that has a significant role in shaping the different attitudes of cadres on various issues.

This study refers to the assumption that PKS dynamics in following the post-reform general elections have changed. These changes include the changes in the regeneration system. This regeneration is at the smallest level, which is within the family by instilling the values and characteristics in family members. Another assumption is that the grouping (factionalism) which occurs in PKS in several decades of the general election, does not affect the PKS vote acquisition. PKS can maintain its existence as an Islamic party with a percentage of votes between $6 \%-8 \%$. As a political party, PKS has carried out the functions of political parties as stated in the laws of political parties, namely political education-the creation of a conducive climate in preserving Indonesia's sovereignty, as a means of absorbing,

${ }^{7}$ Kikue Hamayotsu, "The End of Political Islam? A Comparative Analysis of Religious Parties in the Muslim Democracy of Indonesia”, Journal of Current Southeast Asian Affairs, Volume 30, Issue 3 (2011), 133-159. 
gathering and channeling the political aspirations of the people, people political participation, and political recruitment.

\section{PKS political dynamics}

Negara Kesatuan Republik Indonesia (NKRI; English: Unitary State of the Republic of Indonesia) is one of the countries that adheres to the principle of democracy. Democracy does not manifest by itself. Democracy manifestation comes from a long process and struggle of individuals, groups and other social actors, throughout the country's political life from time to time. ${ }^{8}$ The most basic difference between democracy and other nondemocratic countries such as socialists, communists, and fascists is the element of opposition. The presence of the opposition is expected to be the equilibrium in the state life, as a controller to the state policy.

The political choice of PKS, especially during the reign of Joko Widodo and Jusuf Kalla (Jokowi-JK), was inseparable from the application of a democratic state. The choice of opposition that is played by a political party is one of the main factors of modern democracy. ${ }^{9}$ The PKS political decision pattern in determining their stand as the opposition to the Jokowi-JK government was a collective decision that was motivated by the PKS's desire to maintain democratic stability and control government policies. The position of democracy is more than just the implementation of elections, but democracy is an ideology that contains a set of values that must be embedded, such as participation, tolerance, equality, justice, freedom, universal rights, and mutual consensus. ${ }^{10}$

The PKS policy as an opposition party during the Jokowi-JK

\footnotetext{
${ }^{8}$ Suparman Marzuki, Politik Hukum Hak Asasi Manusia, Jakarta: Erlangga, 2014, 14.

${ }^{9}$ Fanni Mandak \& Peter Smuk,"Institutionalization of Parlimentary Opposition: Comparative Analysis of European Case Studies", 24th World Congress (Politics in a World of Inequality, Poland 23-28 July 2016, Internasional Political Science Association.

${ }^{10} \mathrm{Joseph}$ A. Schumpeter, Capitalism, Socialism, and Democracy, New York: Harper and Row, 1975, 43.
} 
administration was a policy to maintain democracy in Indonesia. The position of the opposition in democracy has several main functions. ${ }^{11}$ First, the opposition functions as the balancing force to the authority. PKS arose as one of the opposition parties in the Jokowi-JK period, which arose as a party outside from the government supporters. These supporters provided alternative policies or attitudes which led to a balance so that the government policies were not too far from the people's interests. Therefore, the PKS policy to maintain the opposition is the same as defending democracy. Second, the opposition has a function in accelerating the policy alternatives. The government in power is not fully supported and chosen by the public through the general elections. As a result, the position of the PKS as an opposition provides the illustration that all aspirations of the community must be accelerated and accommodated by the ruling government. Third, the opposition serves as a stimulus for healthy competition for the political elite and government. PKS gives the stimulus by offering alternative policies directly to the government through a hearing meeting in the Legislative Assembly of the Republic of Indonesia. The PKS oppositional act will make the ruling government "awake" and potentially provide a better policy than before and potentially give "interference" to the government's image in the eyes of the public. In this situation, healthy competition will arise between the ruling government and the opposition in improving the policies.

The position of the PKS in the Jokowi-JK government as the opposition was inseparable from the PKS journey in the previous election. In the 2004 and 2009 presidential elections, PKS was one of the winning political parties and became the coalition of the government under President SBYJK in the 2004-2009 period and SBY-Boediono in the 2009-2014 period.

\footnotetext{
${ }^{11}$ Robert A. Dahl, Poliarchy: Participation and Opposition, London: Yale University Press, 1971, 9 .
} 
In the 2014 presidential election, PKS supported coalition party which suffered from a defeat in carrying out the presidential and vice-presidential candidates. PKS took a policy step by positioning itself as an opposition party. Policy in the PKS decision making is through deliberations. At the level of party policy-making in positioning as an opposition and coalition government is done upon through the Shura Council Assembly.

The PKS ability to run as the opposition party to the Jokowi-JK administration was evidenced by its active roles to conduct criticism and control the government policies that were considered to be contradict to the political vision and ideology of the people. Based on the PKS's AD/ ART (Indonesian: Anggaran Dasar dan Anggaran Rumah Tangga; English: Statutes and Rules of Association), the Shura Council is the highest position in the party organizational structure. The Shura Council functions as an institution Ahlul Halli wal-Aqdi or the Majelis Permusyawaratan Partai (English: Party Consultative Assembly). Shura Council has the task of establishing the basic philosophy of the party's struggle, the party's basic policies, the party's development policy platform, and the party's strategic plan. The policy-making of the Shura Council was carried out through an assembly such as the Musyawarah Majelis Syura (English: Shura Consultative Assembly) which was a high-level assembly of the PKS. Meanwhile, the decision making of the Shura Council was carried out in a manner of ijma (acclamation).

The PKS internal conflict began after the 2004 elections due to differences in party orientation. The difference in orientation is related to leadership and decision making internally within PKS. PKS arose from the struggle and was able to produce solid and loyal supporters due to the regeneration system and the communication patterns that were applied by its members. The communication patterns that were possessed by PKS in conducting the regeneration include the system bayanat (explanation), 
qarar (command), and taklimat (announcement). The PKS communication pattern establishment is the leadership's communication pattern to the structured subordinates, and the highest communication pattern is found in the Shura Council which is the highest assembly in party decisionmaking. The management of political parties does not always run without internal party conflicts. PKS is a political party that has internal conflict problems like other political parties in Indonesia. PKS internal conflicts that occurred in the period before the 2019 elections were very diverse.

\section{The existence of PKS in the era of Jokowi-JK}

The PKS organization and cadre system are stated in the AD/ART PKS (Memorandum and Article of Association). In general, PKS's organizational system and cadre are a form of the existence of political parties which refers to the organizational dimension according to Basedau and Stroh. Basdedau and Stroh look further into the dimensional measurement of an organization through the resources owned by the political party.

The management of an organization of a political party is a management that is carried out by more than two people, meaning that the management is carried out in groups that spread over several regions. Barnard confirms that the organization is a system and work activities that are carried out by two or more people to achieve goals. ${ }^{12}$ Political parties are categorized as organizations because they are carried out by more than two people and are spread over several regions. PKS as a political party has cadres and tenants that spread across several regions in Indonesia. PKS activities can be realized because of the spreading of the people and cadres. They carry out political organization activities through socialization and political education in the community. The organizational system in PKS is based

\footnotetext{
${ }^{12}$ Chester I. Barnard, The Functions of The Executive, Cambridge: Harvard University Press, 1984, 34.
} 
on the Memorandum \& Article of Association consisting of three high institutions, the Shura Council, the Dewan Pimpinan Tingkat Pusat (DPTP; English: Central Level Leadership Council), and the Tahkim Council. Each PKS high institution consists of members who have the autonomy and authority to make the decisions to synchronize the PKS vision and mission.

The dimension in seeing the existence of political parties explained by Basedau and Stroh consists of the aspects of rooting in society, autonomy, organization, and coherence. The organization that was built by PKS in carrying out the activities and political activities towards the cadres under it was carried out in a vertical structure. The strength of the organization of political parties is the reflection of the strength of cadres both at the lower level and at the level of the central leadership that has an important role in a congress that is carried out in determining policies for the development of political parties and the interests of the nation (non-party policies). ${ }^{13}$

Looking at the organizational side, political parties have a function as a means of vertical and horizontal control. ${ }^{14}$ Vertical control is an organizational mechanism regulated through the party's constitution in controlling party structures and management of their management to the lowest level. Whereas horizontal control is a continuation of vertical control which ensures that cadres have important positions in public office or political networks that influence the development of their parties. Based on vertical control, the management of the PKS organization has a top-level management council that has the authority to make decisions that are called the Shura Council. The Shura Assembly has the authority over vertical control which has two functions. First, it has the highest authority outside the national assembly which determines the direction

\footnotetext{
${ }^{13}$ Matthias Basedau \& Alexander Stroh, "Measuring Party Institutionalization in Developing Countries: A New Research Instrument Applied to 28 African Political Parties", GIGA Research Programme: Legitimacy and Efficiency of Political Systems, Series 69 (2008), 1-28.

${ }^{14}$ Ruud A. Koole, "The Vulnerability of the Modern Cadre"...., 287.
} 
and policies in the appointment of individuals as party officials. Second, it has the function to carry out the wheels of party organization and other strategic policies. The PKS cadres' horizontal control aspects lie on several the PKS cadres who have public positions or have closeness with public figures who are influential in making government policy. The distinctive feature of the political party's role in carrying out the vertical control function is to follow the hierarchy of government administration from the central (national), provincial, district/city, sub-district to the village level. As a political party, PKS has cadres who play a role in the winning of each type of election, both at the national and regional levels.

Before the 2004 election, PKS was the former of Partai Keadilan (PK; English: Justice Party) which then increased in number of its cadres in 2004. This point has become a point to transform into a new name for PKS (Indonesian: Partai Keadilan Sejahtera; English: Prosperous Justice Party). The increasing number of cadres is followed by the strength of the party which is the strength of the cadres so that in the 2004 general elections there was an increase in national votes. The strength of PKS cadres can be seen from the vote acquisition in each general election even though the percentage of votes and seats is decreased. The characteristics of PKS are based on the number of cadres with a relatively small number of voters, with a percentage of $2 \%-3 \%$. The characteristic of a political party as a modern cadre party is the relatively small number of cadres, but it has a proportion of the number of voters and has a significant role in the life of the party..$^{15}$ The next characteristic is the role of professional politicians in the PKS which greatly influences policymaking, especially in public and government policymaking.

\footnotetext{
${ }^{15}$ Steven B. Wolinetz, "Beyond the Cath-All Party: Approaches to the Study of Parties and Party Organization in Contemporary Democracies", in Political Party: Old Concepts and New Challenges, New York: Oxford University Press, 2002, 253.
} 
The strength of PKS cadres is developed through the cadre system of preaching movements from the smallest level to the national level by prioritizing commitments (iltizam). The preaching (da'wah) movement that is formed is a cadre movement for the sake of the congregation's life. The congregation life is a human need as a social creature, congregational life is an obligation that is ordered directly by the shari'a. It means that the commitment (iltizam) to the shari'a requires an attitude of commitment to the congregation. Other internal activities of political parties are coherence, which are defined as the ability of political parties to move as a whole and to handle conflicts and disputes within the party. ${ }^{16}$ Coherence is seen through the level of conflicts which occurs internally for conflicts among internal party elites, as well as between individuals and the political parties themselves. PKS has significant dynamics of internal political conflict. The conflict occurred among political elites that resulted in the defection/ dissent of the cadres against political parties. A very striking conflict was the conflict which occurred between Fahri Hamzah and PKS President Moh. Sohibul Iman, which finally led to Fahri's decision to leave the PKS membership and founded a new political party, the Partai Gelombang Rakyat Indonesia (Indonesian: Partai Gelora Indonesia; English: Indonesian People's Wave Party).

This study supports the results of Ufen's research that PKS and PKB have roots in the community especially traditional Muslims; PKB has roots in traditional rural Muslims and PKS has traditional urban Muslim roots. Ufen, through his research on three Southeast Asian countries, Indonesia, the Philippines, and Thailand, reported that the institutionalization of political parties in Indonesia is more advanced than that of the Philippines and Thailand. ${ }^{17}$ Levitsky's opinion related to the view of institutionalization

\footnotetext{
${ }^{16}$ Matthias Basedau \& Alexander Stroh, "Measuring Party Institutionalization..., 9.

${ }^{17}$ Andreas Ufen, "Political Party and Party System Institutionalization in Southeast Asia:
} 
of political parties which is called the existence of a political party is not only seen as a matter of consistency in carrying out procedural tasks and authority of parties. ${ }^{18}$ The existence of ideological values and the attitude of cadres in appreciating the existence of their party is a form of institutionalization of political parties. Political parties have weaknesses in procedural implementation but have advantages in strengthening their ideological values, which then makes political parties able to maintain their existence.

The dimension of autonomy is defined as the ability of political parties to be free from all interventions of interest in party decision making, both from within and outside political parties. PKS decision-making is carried out through the Shura Consultative Assembly which is the highest PKS assembly. All decisions are made through this assembly by promoting the principle of democracy. Moh. Sohibul Iman as the PKS President and Salim Segaf Al Jufri as the Chairman of the PKS Shura Council stressed that the PKS important decision-making process was carried out through the Shura Consultative Assembly and that no party intervened and influenced the decisions. The assembly was purely a PKS cadres' decision which was carried out in phases and the resolution was through the Shura Consultative Assembly. Shura Consultative Assembly has the task of establishing the Basic Philosophy of Party Struggle, the Basic Party Policy, the Party Development Policy Platform, and the Party Strategic Plan. The authority granted by a Chairperson of the Shura Council determines the highest leadership of the PKS, determining the future presidential candidates and future vice-presidential candidates of the Republic of Indonesia, changing and establishes Memorandum \& Article

\footnotetext{
A Comparison of Indonesia, The Philippines and Thailand", The Pacific Review, Series 21, Number 3 (2008), 338.

${ }^{18}$ Steven Levitsky, "Institutionalization and Peronism: The Concept, the Case and the Case for Unpacking the Concept”, Party Politics, Volume 4, Number 1 (1998), 77-92.
} 
of Association of PKS. This research supports the research conducted by Noor, in his research he explained that when compared to PDIP, Golkar, PKB, PPP, PD, PAN, UN, PBR, and PDS, PKS is one of the political parties that can be categorized as an institutionalized political party. It means that the elements of party decision-making autonomy, party internal conflict management, party financial source autonomy, regeneration system, and external relations outside the party occur according to the agreed mechanism. ${ }^{19}$

\section{PKS elite in decision making}

Decision-making can be interpreted as social action which is a necessity in communication. Like Habermas explain that organizational decisionmaking is a strategic action and is oriented towards success in problemsolving. ${ }^{20}$ In the decision-making course, organized communication is needed. Leeper, stressing Habermas' opinion stated that in decision making, communication between sectors within the organization is needed. ${ }^{21}$

The PKS decision-making model is done by bottom-up communication or upward communication model. The upward communication model is a communication model carried out by subordinates to superiors in the form of proposals or suggestions that will be used in decision making of an organization, with the aim of the organization at the top level to accept the proposals of the lower level organizations for the sake of running the organization. ${ }^{22}$ Based on the party Memorandum \& Article

\footnotetext{
${ }^{19}$ Firman Noor, Perpecahan dan Soliditas Partai Islam: Kasus PKB dan PKS di Dekade Pertama Reformasi, Jakarta: LIPI Press, 2015, 572.

${ }^{20}$ Jurgen Habermas, On the Pragmatics of Communication, Cambridge: MIT Press, 1998, 152.

${ }^{21}$ Roy V. Leeper, "Moral Objectivity, Jurgen Habermas's Discourse Ethics, and Public Relations”, Public Relations Reviews, Volume 22, Number 2 (1996), 139.

${ }^{22}$ Heather E. Canary \& Robert D. McPhee, Communication and Organizational Knowledge: Contemporary Issues for Theory and Practice, New York: Taylor and Francis Press, 2011, 86.
} 
of Association, PKS has several types of assembly at each level of the party structure. Assembly is a decision-making principle that is organized by the management of the organizational structure in an official forum under the scope of their respective authorities based on the values of truth, goodness, togetherness, and benefit.

Policy distribution is a process of policy distribution that is ruled in a high-level party assembly to the lower level of the organizational structure down to the cadres and their constituents. The mechanism of policy distribution is often referred to as formal political communication between cadres. The formal communication mechanism is the process of delivering information or decisions in an assembly that flows to the lower level structure. ${ }^{23}$ PKS political communication carried out to the lower cadres is one form of party policy distributions which has been agreed through the Shura Consultative Assembly. This kind of pattern is a formal communication which is realized by the decision of the Shura Consultative Assembly in DPP to the lower level structure of the cadres at the twig level. The decision of the Shura Consultative Assembly was socialized to all levels of the party's highest structure and passed on to the structure at the provincial, district, city, sub-district, village level, to cadres at the twig level.

The political elite is defined as a group of people who have political authority in decision making. Of course, in decision making, the elite has full authority and considers several aspects of politics and aspects of people who influence decision making. The political elite is defined as a person who successfully occupies a high position in a party structure. PKS has the highest level of party structure called the Shura Council, then at the bottom of the structure, there is a DTP which has an important role

\footnotetext{
${ }^{23}$ Ron Ludlow \& Ferhus Panton, The Essence of Effective Communication, New Jersey: Prentice Hall, 1995, 168.
} 
in everyday political dynamics. The next level of PKS structure consists of party structure at the provincial, district/city, sub-district, to the village levels. Each level of the PKS structure has its function and authority in decision making. Therefore, the structural description possessed by PKS can be described as part of each layer in the class. ${ }^{24}$ This means that every level of the PKS structure has people who are in charge and have the authority to make decisions.

The leadership in PKS has a tendency to be narrowed down, meaning that the higher the loyalty and sacrifice of someone towards the party, the person can occupy the top class. The peak of PKS's highest leadership lies in the Shura Council which is gained from various political dynamics and loyalty to the party. The organizational structure of PKS at the central level consists of two main elements namely the Shura Council and the DPTP, where the DPTP consists of MPP, DPP, and DSP. The Shura Council and the DPTP have a strategic function in PKS political dynamics in strategic decision making.

A structured communication mechanism is one that influences the stratification of the political elite in PKS. This research proves that the highest position of the PKS structure is the Shura Council led by the Chairperson of the Shura Council who is elected after the inauguration of the Shura Council members. One of the requirements to become a Chairperson of the Shura Council is a membership period as an Expert Member of at least 12 (twelve) years or has been a Full Member. This means that since PKS was established, a member of the Shura Council is one of the founders of PKS who understands the political dynamics of PKS. The highest position of PKS is obtained through the stages of regeneration starting from the lowest level as the PKS cadres. PKS has a tiered cadre

\footnotetext{
${ }^{24}$ Vilfredo Pareto, The Rise and Fall of Elites: An Application of Theoretical Sociology, New Jersey: Transaction Publishers, 1991, 125.
} 
system, which consists of Supporting Members, Beginner Members, and Core Members. The strata in the regeneration also prove that it occurs in the strata of the political elite in PKS. The types of Full Members and Expert Members are the highest elite strata in the PKS that are occupied by the Shura Council with full authority in governing (elite governing) and decision making. Whereas the non-governing elite is filled in by Expert Members, and the support group strata that do not have the authority in decision making are filled by types of Adult Members, Associate Members, Young Members, Beginner Members, Active Members, and Registered Members.

\section{The efforts to maintain the PKS constituents}

In the PKS journey in the general election which is held every 5 years, the trend shows an increase in the number of votes (despite the fluctuating percentage and seat acquisition). During the Jokowi-JK administration, PKS arose as the government opposition which had the task of checking and balancing the governmental wheel. The policies that are considered to be contrary to the interests of the people will be criticized and provide alternative solutions through political activities both in parliament and outside the parliament.

One of the PKS strategies to win the 2019 general election which was the same as the other political parties in Indonesia was the formation of representatives of political parties up to the village level. In the 2019 general election, PKS had 34 provincial DPWs at the provincial level, at the regency/city level PKS had 477 DPD from 514 districts/cities or $92.80 \%$ of the regional administration, and it had 5,069 DPC from 7,094 districts or $71.45 \%$. The management that was formed up to the village level is one of the PKS strategies to broaden the voter base in the 2019 general elections. The built structures at the village level are fostered through regeneration 
to increase the solidity and loyalty of cadres so that cadres can influence voters to vote for PKS in the 2019 general elections.

The campaigns that were conducted by PKS can be said to be very simple, by using only simple words but having a direct influence on the PKS votes. PKS realizes that the basic needs of the community and the willingness of the people are to be free from poverty. PKS provided an opportunity for the general public to support it as the winner in the 2019 general elections so that PKS could fulfill and implement its political promises. The relatively high number of PKS votes in the 2019 general elections illustrates the hard work of all the elements of PKS, ranging from the structure of central and regional legislative members candidates, the campaign team, wing organizations, and sympathizers. The 2019 DPR RI (English: RI House of Representatives, legislative) general election win was the main aspect of winning the national general election. PKS has a general policy in placing candidates who have the capacity and capability to solve problems in society. In the 2019 general elections, PKS DPR RI candidates were 533 candidates and were able to get as many as 50 seats.

The form of communication established by PKS is to prioritize the principles of intellectual values in the development of science. PKS possessed the political concept of ideas that becomes a communication tool for candidates, cadres and sympathizers, which finally PKS formulated into four policy points, namely (1) life-long SIM, (2) freeing motor vehicle tax, (3) fighting for the ulama protection law, and (4) exempting income tax for the people who earn less than 8 million per month. The communication and networking of public relations that was built by PKS is an application of the regular preaching movement, but ahead of the 2019 general elections, the preaching movement was intended to arouse the cadre's enthusiasm in moving and winning the election. So that it would be embedded in the cadres of PKS, the consistency values in conducting political education for 
cadres. The cadres in communicating with the voters prioritized human values and care for the community. The PKS communication that was carried out was to use the slogan in the 2019 general election which was "Berkhidmat untuk Rakyat" (English: "Serving for the People"). The slogan or jargon was one form of PKS in maintaining constituents in the voter base.

The strength of political parties is in the constituents, therefore it is important in maintaining the relationship between political parties and constituents. With the results of the 2019 general election, PKS faced a new chapter of struggle in the dynamics of Indonesian politics. Where the PKS revival which was based on the results of the 2019 general election vote must be able to be a public representation. PKS had a great responsibility towards the constituents and the people who have voted for PKS. Of course, the success of the PKS in 2019 in gaining the vote could not be separated from the active role of constituents on the electoral basis. The relationship between constituents and PKS is carried out through legislative candidates both at the central and regional levels. The relationship was created because the community felt they had the representatives of the people or had held meetings in person. Polsby said that the legislative institution is the institution that is considered as the closest institution to the community, an institution which is a branch of government that can access the people..$^{25}$

The strategy of building a new network and utilizing the resources of the PKS had proven successful in gaining PKS votes in the 2019 general election when compared to the 2014 general election. The increase in PKS votes in the 2019 general elections was by $35.54 \%$ or $3,013,459$ votes, an increase from the 2014 general elections of 8,480,204 votes and the 2019 elections by 11,493,663 votes. Based on the strategy of maintaining

${ }^{25}$ Nelson W. Polsby, "Legislatures", in Handbook of Political Science: Government Institutions and Processes, Boston: Addison Wesley, 1975, 185. 
constituents in expanding networks and optimizing the available resources, according to Schroder what is called the offensive strategy is employing a market expansion strategy (competitive strategy) and a market penetration strategies (client strategy). ${ }^{26}$ PKS did not implement an overall defensive strategy, as Schroder argues in maintaining relations with constituents. The PKS defensive strategies were to maintain the voters and strengthen the seasonal voters, such as the constituents who consisted of the voters, sympathizers, and the general public. Whereas the defensive strategy carried out by releasing voters was not carried out by PKS even though it was not a voter base area.

\section{Conclusion}

The existence of PKS in the Jokowi-JK era can be seen in the role of PKS as the government's opposition. PKS has a strong regeneration system that other parties in Indonesia do not have, namely through tarbiyah in the form of halaqah. Tarbiyah is carried out as a means of regeneration which is carried out regularly and has a structured curriculum. The tarbiyah movement in the form of da'wah as a form of regeneration is carried out by PKS regularly to protect cadres and constituents. The use of identity politics can increase public participation in using their voting rights in every election, the use of identity politics on the electoral side has a significant effect on the votes acquired by certain group-based political parties such as PKS which is the representative party of Islamic groups. For further research, it is necessary to compare the existence of Islamic-based political parties in Indonesia which have a role as opposition or a coalition of the ruling government.

\footnotetext{
${ }^{26}$ Peter Schroder, Political Strategy, Germany: Nomos, 2005, 485.
} 
The Dynamics and Existence of Islamic Party in 2019... (Muh. Haris, et. al)

\section{Bibliography}

Barnard, Chester I. The Functions of The Executive. Cambridge: Harvard University Press, 1984.

Basedau, Matthias, \& Stroh, Alexander, "Measuring Party Institutionalization in Developing Countries: A New Research Instrument Applied to 28 African Political Parties", GIGA Research Programme: Legitimacy and Efficiency of Political Systems, Series 69 (2008): 1-28.

Canary, Heather E., \& McPhee, Robert D. Communication and Organizational Knowledge: Contemporary Issues for Theory and Practice. New York: Taylor and Francis Press, 2011.

Dahl, Robert A. Polyarchy: Participation and Opposition. London: Yale University Press, 1971.

Habermas, Jurgen. On the Pragmatics of Communication. Cambridge: MIT Press, 1998.

Hamayotsu, Kikue. "The End of Political Islam? A Comparative Analysis of Religious Parties in the Muslim Democracy of Indonesia”, Journal of Current Southeast Asian Affairs, Volume 30, Issue 3 (2011): 133-159.

Koole, Ruud A., "The Vulnerability of the Modern Cadre Party in the Netherlands”, in R. S. Katz \& P. Mair (Eds.). How Parties Organize: Change and Adaptation in Party Organizations in Western Democracies. London: SAGE Publications, Inc., 1994.

Leeper, Roy V., "Moral Objectivity, Jurgen Habermas's Discourse Ethics, and Public Relations”, Public Relations Reviews, Volume 22, Number 2 (1996): 133-150.

Levitsky, Steven, "Institutionalization and Peronism: The Concept, the Case and the Case for Unpacking the Concept", Party Politics, Volume 4, Number 1 (1998): 77-92.

Ludlow, Ron, \& Panton, Ferhus. The Essence of Effective Communication. New Jersey: Prentice-Hall, 1995.

Mandak, Fanni, \& Smuk, Peter, "Institutionalization of Parliamentary Opposition: Comparative Analysis of European Case Studies”, 24th World Congress (Politics in a World of Inequality, Poland 23-28 July 2016, Internasional Political Science Association.

Marzuki, Suparman. Politik Hukum Hak Asasi Manusia. Jakarta: Erlangga, 2014. Noor, Firman. Perpecahan dan Soliditas Partai Islam: Kasus PKB dan PKS di Dekade Pertama Reformasi. Jakarta: LIPI Press, 2015. 
IJIMS: Indonesian Journal of Islam and Muslim Societies, Volume 10, Number 2, December 2020: 409-432

Pareto, Vilfredo, The Rise and Fall of Elites: An Application of Theoretical Sociology. New Jersey: Transaction Publishers, 1991.

Polsby, Nelson W., "Legislatures", in Handbook of Political Science: Government Institutions and Processes. Boston: Addison Wesley, 1975.

Romli, Lili. "Partai Islam dan Pemilih Islam di Indonesia", Jurnal Penelitian Politik, Volume 1, No. 1 (2004): 29-48.

Saputra, Ali Thaufan Dwi. Pergolakan Partai Islam di Tahun Politik. Jakarta: Yayasan Pustaka Obor Indonesia, 2019.

Schroder, Peter. Political Strategy. Germany: Nomos, 2005.

Schumpeter, Joseph A. Capitalism, Socialism, and Democracy. New York: Harper and Row, 1975.

Tomsa, Dirk, "Moderating Islamism in Indonesia: Tracing Patterns of Party Change in the Prosperous Justice Party", Political Research Quarterly, Volume 65, Number 3 (2012): 486-498.

Turmudi, Endang, "Islamic Politics in Contemporary Indonesia", International Journal of Political Studies, Volume 2, Number 3 (2016): 1-9.

Ufen, Andreas. "Political Party and Party System Institutionalization in Southeast Asia: A Comparison of Indonesia, The Philippines and Thailand", The Pacific Review Series 21, Number 3 (2008): 328-350.

Umam, Ahmad Khoirul, \& Junaidi, Akhmad Arif, "Political Islam: The Shrinking Tren and The Future Trajectory of Islamic Political Parties in Indonesia", Masyarakat, Kebudayaan dan Politik, Volume 30, Number 1 (2017): 1-12.

Wolinetz, Steven B., "Beyond the Cath-All Party: Approaches to the Study of Parties and Party Organization in Contemporary Democracies", in Political Party: Old Concepts and New Challenges. New York: Oxford University Press, 2002: 231-273. 